\title{
Fechamento do balanço de energia em uma floresta tropical: contribuições da troca
}

\section{turbulenta e armazenamento de calor ecossistema}

Energy balance closure in a tropical forest: contributions of turbulent exchange and ecosystem heat storage

Paul C. Stoy ${ }^{a}$, Tobias Gerken ${ }^{b}$, Jose D. Fuentes ${ }^{b}$, Rosa M. Nascimento dos Santos ${ }^{\mathrm{c}}$, Celso Von Randow ${ }^{\mathrm{d}}$, Jair Max Furtunato Maia ${ }^{\mathrm{c}}$, Antonio Manzi ${ }^{\mathrm{e}}$, Marcelo Chamecki ${ }^{\mathrm{b}}$,

${ }^{\mathrm{b}}$ Department of Meteorology, The Pennsylvania State University, University Park, PA, USA

${ }^{a}$ Department of Land Resources and Environmental Sciences, Montana State University, Bozeman, MT, USA

\author{
${ }^{c}$ Universidade do Estado do Amazonas, Manaus, AM, Brazil \\ ${ }^{\mathrm{d}}$ National Institute for Space Research (INPE), São José dos Campos, SP, Brazil \\ ${ }^{\mathrm{e}}$ Instituto Nacional de Pesquisas da Amazônia (INPA), Manaus, AM, Brazil
}

\begin{abstract}
The surface energy balance is rarely closed using the common half-hourly averaging period for turbulent fluxes as eddies of greater characteristic time scales often provide a non-trivial contribution to energy exchange. Here, we briefly discuss previous efforts to improve surface energy balance closure of a tropical rainforest ecosystem - the K34 site - and describe how measurements from the GoAmazon campaign can be used to improve our understanding of energy flux and storage in tropical canopies.
\end{abstract}

\section{Resumo}

O balanço de energia da superfície raramente é fechado usando o período médio a cada meia hora comum para fluxos turbulentos como turbilhões de maior tempo característico escalas costumam oferecer uma contribuição não-trivial para troca de energia. Aqui, discutimos brevemente os esforços anteriores para melhorar o fechamento do balanço de energia da superfície de uma floresta tropical ecossistema tropical - o site K34 - e descrever como medições da campanha GoAmazon pode ser usado para melhorar a nossa compreensão do fluxo de energia e armazenamento em copas tropicais.

Keywords: eddy covariance, energy exchange, net radiation, soil heat flux, turbulent flux 


\section{Introduction}

Eddy covariance and micrometeorological measurements rarely close the surface energy balance (Wilson et al. 2002), which compromises our ability to study the flux of water and energy between ecosystems and the atmosphere. Many studies argue that atmospheric motions longer than the averaging time of the eddy covariance system - typically one half hour - are primarily responsible for the lack of energy balance closure (Foken 2008; Foken et al. 2011; Stoy et al. 2013). To this end, Malhi et al. (2002) noted that the energy balance of a central Amazonian rainforest was closed when the eddy covariance averaging period was extended to $1-4$ hours, implying that larger eddies are sufficiently captured with longer averaging periods.

The challenge with such an analysis is that longer averaging periods can obscure important details in the diurnal patterns of energy surface-atmosphere exchanges. Recent efforts to 'optimize' the ogive function used to characterize the contribution of eddies with different characteristic frequencies in the time domain (Sievers et al. 2015) may prove useful for quantifying the diurnal pattern of energy flux between the surface and atmosphere and energy storage in the canopy and soils. Coupling an optimized eddy covariance processing scheme with heat transfer and storage observations within the canopy will improve our understanding of surfaceatmosphere exchanges in the globallyimportant tropical forest ecosystem.

\section{Methods}

Experimental methods are detailed in Fuentes et al. (2015) and briefly summarized here. Subcanopy and above canopy eddy covariance measurements were made at 1.5 $\mathrm{m}$ and $39 \mathrm{~m}$ across the wet-to-dry season transition from April 2014 to January 2015 at the Cuieiras Biological Reserve located
$60 \mathrm{~km}$ north-northwest of the City of Manaus, Amazonas, Brazil at the K34 tower site $\left(2^{\circ} 36^{\prime} 33.31^{\prime \prime} \mathrm{S}, 60^{\circ} 12^{\prime} 32.58^{\prime \prime} \mathrm{W}\right)$, the same forest explored by Malhi et al. (2002). Soil heat flux was measured at eight locations near subcanopy tower at $5 \mathrm{~cm}$ below the soil surface. Six soil temperature measurements were made at $5 \mathrm{~cm}$ depth and a profile measured soil temperature and moisture at 25, 50 and $75 \mathrm{~cm}$ below the surface. A four-component radiometer measured incident and outgoing shortwave and longwave radiation at $1.5 \mathrm{~m}$ above the surface.

\section{Results}

Results demonstrate that soil heat flux contributes only about $10 \mathrm{~W} \mathrm{~m}^{-2}$ of energy flux during peak daytime periods (Figure 1), as a result of subcanopy incident shortwave radiation fluxes that average nearly $30 \mathrm{~W} \mathrm{~m}^{-}$ 2 at their peak but can have a large standard deviation at noon of over $50 \mathrm{~W} \mathrm{~m}^{-2}$ owing to sunfleck dynamics (Figure 2). Above canopy net radiation measurements approach $800 \mathrm{~W} \mathrm{~m}^{-2}$ during peak periods during the dry season and peak latent and sensible heat fluxes of about 400 and $200 \mathrm{~W}$ $\mathrm{m}^{-2}$, respectively (Fuentes et al. 2015), suggesting that the surface energy balance is not closed by the conventional approach of comparing available energy (net radiation minus soil heat flux) versus the sum of turbulent fluxes. In other words, energy storage in the canopy air space and aboveground canopy elements, and energy flux owing to photosynthetic processes must be accounted for to close the surface energy balance at this site (Malhi et al. 2002), and the half-hour averaging period is likely insufficient to measure the contributions of larger eddies that make nontrivial contributions to the surface energy balance. 


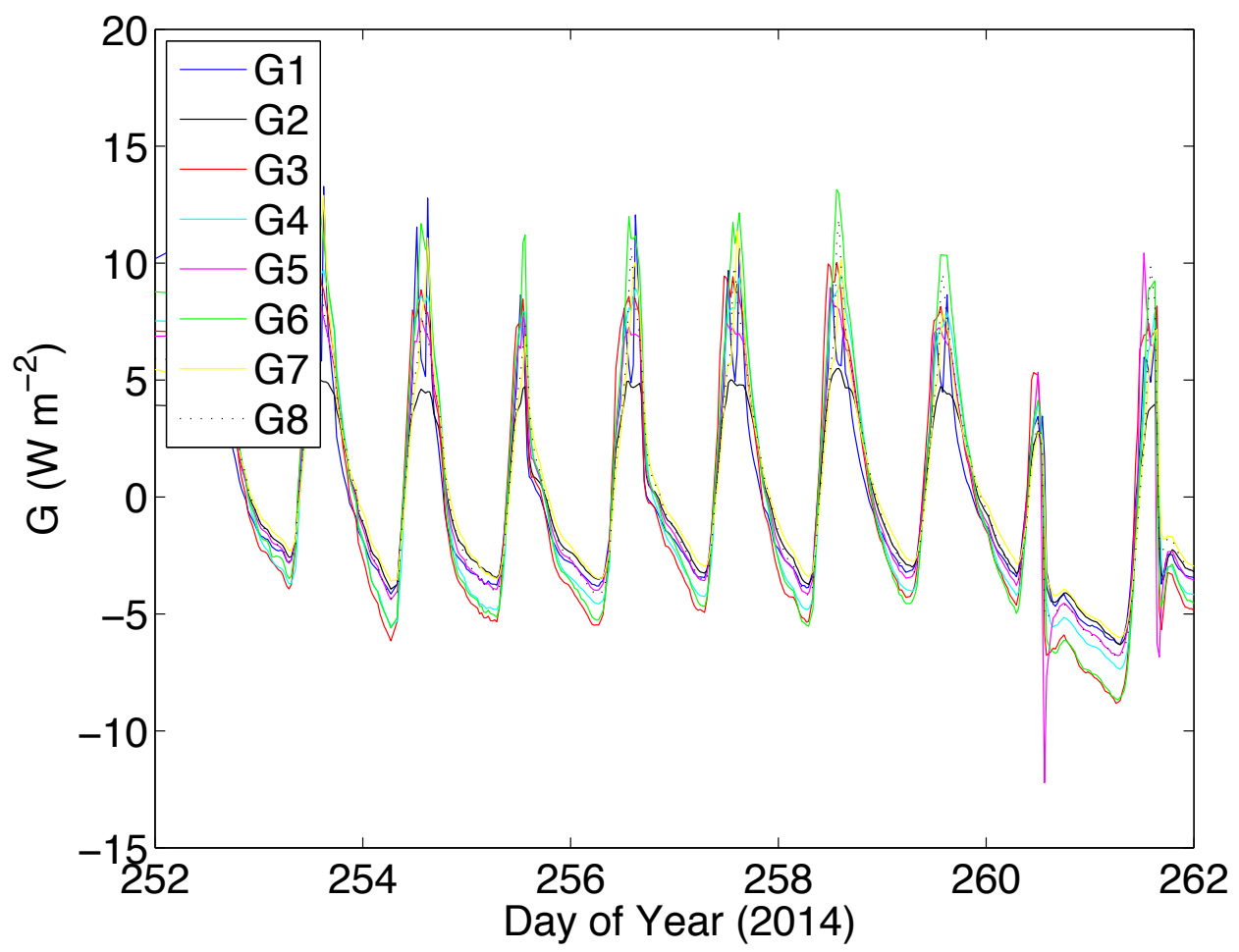

Figure 1. Soil heat flux (G) measured using eight soil heat flux plates placed at $5 \mathrm{~cm}$ depth at the K34 study site. The impacts of a large rain event are visible on days of year 260-261.

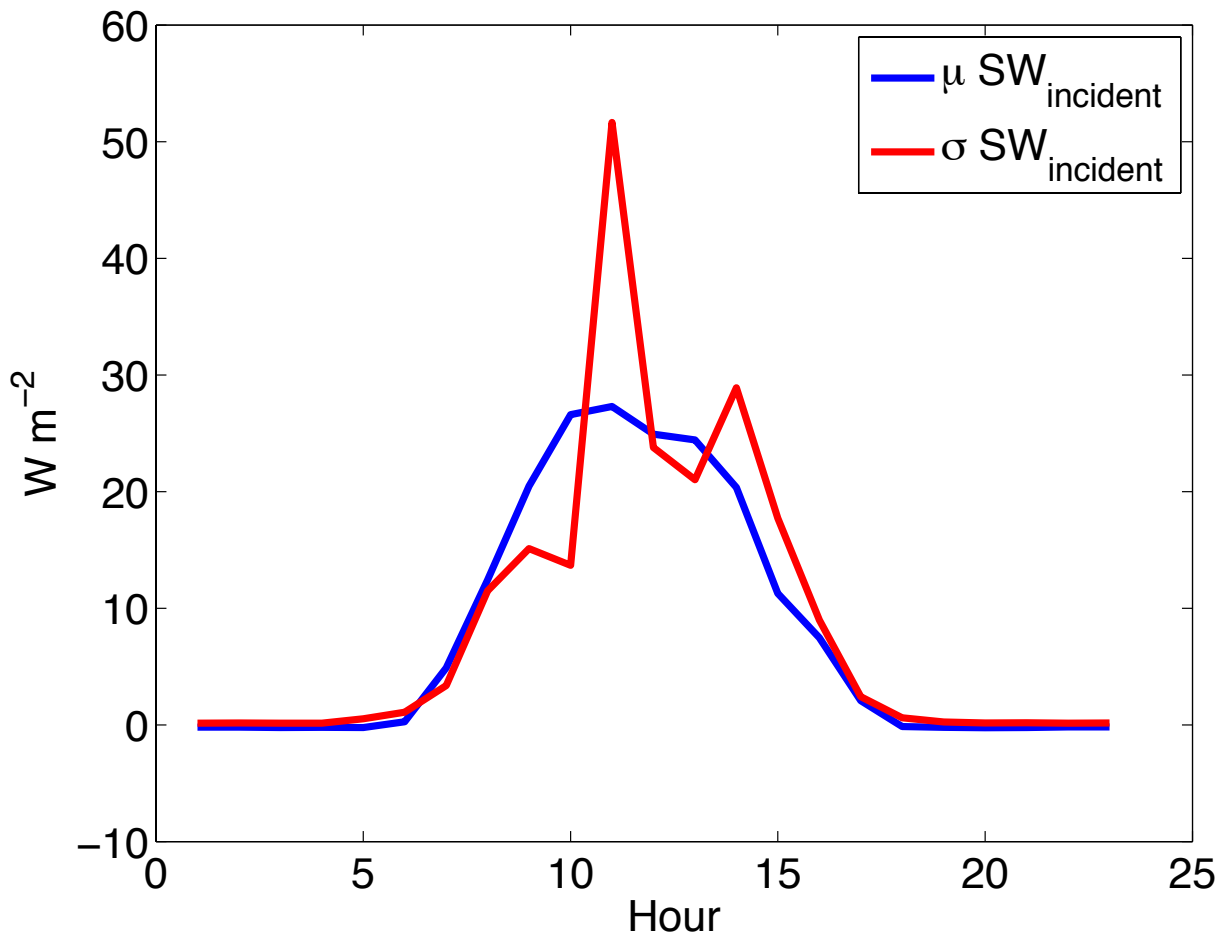

Figure 2. Diurnal patterns of the mean and averaged standard deviation of the incident shortwave radiation flux ( $\mathrm{SW}_{\text {incident }}$ ) below the forest canopy at $1.5 \mathrm{~m}$ at the $\mathrm{K} 34$ study site. 


\section{Conclusions}

The surface energy balance of the K34 site is not closed using the conventional approach of employing half-hourly turbulent flux observations, but Malhi et al. (2002) were able to approach surface energy balance closure by extending the length of the averaging period to 1-4 hours. An extended suite of sensors available during the intensive GoAmazon campaign (Fuentes et al. 2015) provide us the opportunity for further studies about the contributions of turbulent exchange within the canopy and between the surface and the atmosphere as well as heat storage within the above canopy elements, the canopy air space, and the soil to improve our understanding of energy flux at the forest-atmosphere interface in the tropics.

\section{Acknowledgements}

The U.S. Department of Energy supported the field studies as part of the GoAmazon project (grant SC0011075). Fundação de Amparo à Pesquisa do Estado de São Paulo (FAPESP) and Fundação de Amparo à Pesquisa do Estado do Amazonas (FAPEAM) funded the Brazilian component of the field studies. The Large scale Biosphere-Atmosphere Experiment in Amazonia (LBA) provided logistic support and made the flux tower and housing unit available to complete the field studies. The field project would have not been possible without the assistance of several Brazilian undergraduate and graduate students

\section{References}

Foken, Thomas. 2008. "The Energy Balance Closure Problem: An Overview." Ecological Applications 18(6): 135167.

\section{1. "Results of a Panel}

Discussion about the Energy Balance Closure Correction for Trace Gases." Bulletin of the American Meteorological Society 92(4): ES1318 .
Fuentes, JD et al. 2015. "Linking

Meteorology, Turbulence, and Air

Chemistry in the Amazon Rainforest during the GoAmazon Project."

Bulletin of the American

Meteorological Society: in review.

Malhi, Y et al. 2002. "Energy and Water Dynamics of a Central Amazonian Rain Forest." Journal of Geophysical Research 107(D20): 8061.

Sievers, J et al. 2015. "Estimating Surface Fluxes Using Eddy Covariance and Numerical Ogive Optimization." Atmospheric Chemistry and Physics 15(4): 2081-2103.

Stoy, PC et al. 2013. "A Data-Driven Analysis of Energy Balance Closure across FLUXNET Research Sites: The Role of Landscape Scale Heterogeneity." Agricultural and forest meteorology 171: 137-52.

Wilson, K et al. 2002. "Energy Balance Closure at FLUXNET Sites." Agricultural and Forest Meteorology 113: 223-43. 